\title{
PENGARUH MODEL PEMBELAJARAN KOOPERATIF TIPE NUMBERED HEAD TOGETHER (NHT) TERHADAP HASIL BELAJAR DAN KEMAMPUAN BERTANYA SISWA PADA MATERI SISTEM PERNAPASAN MANUSIA DI KELAS XI IPA SMA N 1 KUTALIMBARU
}

\author{
Nurhasanah Sihotang ${ }^{{ }^{*}}$, Ely Djulia $^{2}$, Sentosa Gurusinga ${ }^{3}$ \\ ${ }^{1,2}$ Prodi Pendidikan Biologi, FMIPA, Universitas Negeri Medan, Jl. Willem Iskandar Psr. V Medan Estate, Medan, \\ Indonesia, 20221 \\ ${ }^{3}$ SMA N 1 Kutalimbaru, Jalan Pendidikan, Pasar IV, Desan Suka Rende, Kec. Kutalimbaru, Kab. Deli Serdang 20354 \\ *E-mail : sihotangnurhasanah@gmail.com
}

\begin{abstract}
ABSTRAK
Penelitian ini bertujuan untuk mengetahui adanya pengaruh signifikan hasil belajar dan kemampuan bertanya siswa dengan menggunakan model pembelajaran kooperatif tipe numbered head together (NHT) pada materi sistem pernapasan manusia di kelas XI IPA SMA N 1 Kutalimbaru Tahun Pembelajaran 2016/2017. Populasi dalam penelitian ini adalah seluruh siswa kelas XI IPA SMAN 1 Kutalimbaru Tahun Pembelajaran 2016/2107 yang terdiri dari 3 kelas yang berjumlah 116 siswa. Sampel dalam penelitian ini diambil secara acak (random sampling) dengan jumlah siswa sebanyak 80 orang yaitu kelas XI IPA 1 merupakan kelas eksperimen menggunakan model pembelajaran kooperatif tipe numbered head together (NHT) dengan jumlah siswa 40 orang sedangkan XI IPA 3 sebagai kelas kontrol menggunakan metode ceramah dan tanya jawab dengan jumlah siswa 40 orang. Jenis penelitian ini adalah quasi eksperimen. Berdasarkan nilai rata-rata terlihat adanya pengaruh hasil belajar dan kemampuan bertanya siswa dengan menggunakan model pembelajaran kooperatif tipe Numbered Head Together (NHT) dimana nilai postest kelas siswa pada kelas eksperimen sebesar 82,9 dan SD sebesar 6,3. Sedangkan nilai rata-rata pada kelas kontrol sebesar 79,25 dengan SD sebesar 5,86. Adanya pengaruh hasil belajar tersebut juga terbukti melalui pengujian hipotesis dengan menggunakan uji $t$ dan taraf kepercayaan $\alpha=0,05$, dimana $t_{\text {hitung }}>t_{\text {tab }}(6,66>2,001)$, yang berarti dalam penelitian ini $\mathrm{H}_{0}$ ditolak dan $\mathrm{H}_{a}$ diterima. Nilai rata-rata kemampuan bertanya siswa pada kelas eksperimen yaitu $60,5 \%$ dengan predikat cukup baik dan kelas kontrol 32,5\% dengan predikat kurang baik. Sehingga dapat disimpulkan bahwa ada pengaruh yang signifikan menggunakan model pembelajaran kooperatif tipe numbered head together (NHT) terhadap hasil belajar dan kemampuan bertanya siswa pada materi sistem pernapasan manusia di kelas XI IPA SMA N 1Kutalimbaru Tahun Pembelajaran 2016/2017.
\end{abstract}

Kata kunci: Hasil belajar, Model kooperatif Numbered Head Together, Sistem Pernapasan Manusia

\section{ABSTRACT}

This research aim to know whether is a significant influence learning result and ability to ask student by using cooperative learning model numbered head together (NHT) in human respiratory system subject matter grade XI science senior high school 1 Kutalimbaru academic year 2016/2017. The population in this research is all students that consist of 3 classes totaling 116 students. The sample was taken in random sampling as many as 80 students. XI IPA 1 is an experimental class using cooperative learning model numbered head together (NHT) as many as 40 students, while XI IPA 3 as the control class using lecture and question and answer method as many as 40 students. Th method of this research is quasi-experimental. Based on the average value seen their influence learning result and the ability to ask student by using cooperative learning model numbered head together (NHT) which indicate that the value posttest students in the experimental class is 82.9 and SD 6.3. While the average value in the control class is 79.25 with SD of 5.86 . The influence of learning result is also proven through hypothesis testing by using $t$ test with the level of trust $\alpha=0,05$, where $t$ count $>t$ tab $(6,66>2,001)$, which means in this research Ho rejected and $\mathrm{Ha}$ accepted. The average score of student ability ask in the experimental class is $60,5 \%$ belongs to good predicate and control class is $32,5 \%$ belongs to bad predicate. It can be concluded that there is significant influence using cooperative learning model numbered head together (NHT) for learning result and the ability to ask student in human respiratory system subject matter in grade XI science senior high school 1 Kutalimbaru T.P. 2016/2017.

Keywords: Learning result, Cooperative Learning Type Numbered Head Together, Human Respiratory System. 
JURNAL PELITA PENDIDIKAN VOL. 5 NO. 4

Sihotang, N., Djulia, E., Gurusinga, S.

Halaman : $389-397$

\section{PENDAHULUAN}

Sistem pernapasan manusia adalah sistem organ yang terjadi dalam tubuh manusia. Pada materi ini siswa sudah mengetahui alat-alat pernapasan manusia, pernafasan dada, dan kelainan alat pernapasan seperti influenza, asma, dan sesak napas. Dalam materi sistem pernapasan manusia terdapat kompetensi dasar yang harus dicapai dalam pembelajaran yaitu menganalisis hubungan antara struktur jaringan penyusun organ pada sistem pernapasan dan mengaitkannya dengan bioprosesnya sehingga dapat menjelaskan proses pernapasan serta gangguan fungsi yang mungkin terjadi pada sistem pernapasan manusia melalui studi literatur, pengamatan, percobaan, dan simulasi. Dan untuk mencapai kompetensi dasar tersebut diperlukan suatu model pembelajaran yang yang dapat meningkatkan pengetahuan akademik, rasa antusias, berpikir kritis, dan rasa percaya diri siswa.

Berdasarkan hasil wawancara dengan guru bidang studi Biologi di SMA N 1 Kutalimbaru bahwa sejauh ini pembelajaran Biologi yang dilakukan masih menggunakan metode konvensional yaitu ceramah. Pembelajaran Biologi masih berpusat pada guru sebagai pemberi ilmu pengetahuan pada peserta didik, penyampaian materi pembelajaran cenderung didominasi dengan metode ceramah serta siswa yang jarang bertanya kepada guru . Akibatnya peserta didik kurang aktif dalam proses pembelajaran dan untuk membangun serta menemukan sendiri melalui interaksi dengan lingkungannya.

Biologi merupakan mata pelajaran yang membutuhkan pemahaman. Pembelajaraan kooperatif yang memungkinkan siswa berdiskusi dan bertukar pikiran dengan temannya dapat memudahkan pemahaman dalam mempelajari materi Biologi. Berdasarkan karakteristik dan fenomena pembelajaran disekolah selama ini bahwa sebagian besar siswa kurang aktif berinteraksi antara siswa denga siswa, siswa dengan guru baik melalui pertanyaan maupun mengajukan pendapat pada saat kegiatan pembelajaran di kelas.

Pembelajaran biologi berlangsung bersifat teoritis. Pembelajaran masih berorientasi pada upaya penguasaan materi sebanyak-banyaknya pada siswa tanpa diikuti sikap dan keterampilan penerapan dalam
pISSN : 2338 - 3003

elSSN : $2502-3217$

kehidupan sehari-hari. Akibatnya pembelajaran cenderung berlangsung satu arah dengan guru sebagai sumber belajar utama. Prosesnya adalah guru sebagai pusat pembelajaran aktif menyampaikan materi dengan metode ceramah, latihan dan penugasan sebagai pilihan utama. Sementara guru aktif, siswa pasif menerima materi menjadi pendengar yang budiman.

Materi sistem pernapasan manusia merupakan salah satu materi Biologi yang memiliki cakupan yang cukup luas sehingga dibutuhkan pemahaman yang tinggi agar kompetensi dasar di Sekolah Menengah Atas tentang materi tersebut tercapai. Pada materi ini siswa biasanya hanya menghafal bagaimana sistem pernapasan manusia tanpa memahaminya. Kegiatan menghafal yang dibuat guru membuat siswa lebih cepat lupa tentang materi tersebut sehingga apabila dievaluasi kembali siswa kebanyakan tidak mampu menjelaskan kembali. Padahal kompetensi yang diharapkan dalam pembelajaran Biologi menuntut peserta didik agar lebih maksimal dalam belajar Biologi. Peserta didik tidak hanya dituntut menguasai konsep dan teori saja, tetapi harus dapat menghubungkan materi dengan kehidupan sehari-hari sehingga pembelajaran lebih bermakna dan dapat meningkatkan keaktifan dan hasil belajar peserta didik.

Berdasarkan pengamatan penulis di SMA N 1 Kutalimbaru pembelajaran Biologi masih berpusat pada guru sebagai pemberi ilmu pengetahuan pada peserta didik, penyampaian materi pembelajaran cenderung didominasi dengan metode ceramah. Akibatnya peserta didik kurang aktif dalam proses pembelajaran dan untuk membangun serta menemukan sendiri melalui interaksi dengan lingkungannya. Hasil wawancara dengan guru Biologi SMA N 1 Kutalimbaru bahwa lebih kurang 55 \% siswa dari seluruh populasi mendapat nilai <75 dengan rata rata 65 , dimana kriteria ketuntasan minimal (KKM) mata pelajaran Biologi di sekolah tersebut adalah 75. Dari keterangan yang disampaikan guru tersebut, masalah yang terjadi dalam proses pembelajaran yaitu kurangnya keaktifan siswa dalam proses belajar mengajar, seperti siswa tidak memperhatikan guru, siswa enggan bertanya ketika diberikan suatu pertanyaan dan sangat sedikit 
siswa yang mau menjawab pertanyaan guru serta siswa lebih banyak diam ketika dimintai pendapat.

Numbered Head Together merupakan model pembelajaran kooperatif yang dapat merangsang pola interaksi dan keaktifan peserta didik, karena setiap peserta didik mempunyai tanggungjawab secara individual terhadap pembelajaran dalam diskusi kelompok sehingga menjadikan peserta didik selalu siap dan tidak lagi bergantung pada temannya. Pada model ini siswa dikelompokkan dalam beberapa kelompok kecil yang terdiri dari 5-6 orang peserta didik dan diberi nomor. Selanjutnya peserta didik diberikan materi kepada setiap kelompok serta kesempatan untuk berdiskusi dengan anggota kelompoknya dalam memecahkan masalah, menyampaikan temuan, bertanggung jawab dalam menyelesaikan tugas serta membantu kelompok lain dalam menyelesaikan masalah melaui tanggapan. Sehingga peserta didik diharapkan dapat memahami dan menerapkan konsep serta dapat lebih aktif dalam pembelajaran. Menurut Dewi dan Yunansyah (2013), pembelajaran kooperatif tipe NHT dapat melatih siswa untuk saling berbagi informas, mendengar dengan cermat serta berbicara sesuai pendapat mereka masing-masing sehingga siswa dapat lebih aktif dalam pem\belajaran.

Dalam penelitian yang dilakukan ZuLfah (2015) bahwa penerapan model NHT pada pembelajaran sistem pencernaan makanan dapat meningkatkan kemampuan peserta didik pada materi sistem pencernaan makanan di kelas VII SMP N Comal dan juga meningkatkan sikap dan minat siswa. Dalam penelitian yang dilakukan Pakpahan dan Riwayati (2016) tentang perbedaan hasil belajar siswa mengugunakan model pembelajaran kooperatif tipe Numbered Head Together dengan tipe Think Pare Share pada materi pokok ekosistem di kelas VII diperoleh nilai hasil belajar akhir lebih tinggi pada model NHT daripada TPS yaitu 76,8, sehingga penulis juga ingin membuktikan bahwa model NHT (Numbered Head
Together) ini dapat meningkatkan hasil belajar di SMA N 1 Kutalimbaru.

Tujuan penelitian ini adalah untuk hasil belajar siswa pada materi sistem pernapasan manusia dengan menggunakan model pembelajaran kooperatif tipe Numbered Head Together di kelas XI IPA SMA N 1 Kutalimbaru, untuk mengetahui kemampuan bertanya siswa pada materi sistem pernapasan manusia dengan menggunakan model kooperatif tipe Numbered Head Together di kelas XI IPA SMA N 1 Kutalimbaru, dan ntuk mengetahui pengaruh model pembelajaran kooperatif tipe Numbered Head Together terhadap hasil belajar dan kemampuan bertanya siswa pada materi sistem pernapasan manusia di kelas XI IPA SMA N 1 Kutalimbaru T.P. 2016/2017.

\section{METODE PENELITIAN}

Penelitian ini dilaksanakan di SMA N 1 Kutalimbaru yang beralamat di Jalan Pendidikan, Pasar IV, Desa Suka Rende, Kecamatan Kutalimbaru, Kabupaten Deli Serdang Provinsi Sumatera Utara Kode pos 20354 pada bulan April sampai Juni Tahun 2017. Populasi dalam penelitian ini adalah seluruh siswa kelas XI IPA SMA N 1 Kutalimbaru yang terdiri dari 3 kelas dimana Kelas XI IPA 1 berjumlah 40 orang, XII IPA 2 berjumlah 36 orang dan XI IPA 3 berjumlah 40 orang sehingga jumlah keseluruhan populasi adalah 116 orang dan sampel dalam penelitian ini adalah siswa di kelas XI IPA $1 \mathrm{~S}$ berjumlah 40 orang sebagai kelas eksperimen dan XI IPA 3 berjumlah 40 orang sebagai kelas kontrol. Sampel tersebut diambil dengan teknik random sampling. Jenis Penelitian ini merupakan Penelitian quasi eksperimen. Desain penelitian yang digunakan dalam penelitian ini adalah seperti yang tampak pada Tabel 1 berikut. 
Tabel 1. Desain penelitian Two Group (Pretest-Postest)

\begin{tabular}{lccc}
\hline \multicolumn{1}{c}{ Kelompok } & Pretest & Perlakuan & Post test \\
\hline Eksperimen & $\mathrm{T}_{1}$ & $\mathrm{X}_{1}$ & $\mathrm{~T}_{2}$ \\
Kontrol & $\mathrm{T}_{1}$ & $\mathrm{X}_{2}$ & $\mathrm{~T}_{2}$ \\
\end{tabular}

Keterangan:

$\mathrm{T}_{1}$ : Tes Kemampuan awal siswa (soal)

$\mathrm{T}_{2}$ : Tes Kemampuan akhir siswa (soal)

$\mathrm{X}_{1}$ : Perlakuan yang diberikan pada kelas eksperimen dengan menerapkan Numbered Head Together

$\mathrm{X}_{2}$ : Perlakuan yang diberikan pada kelas kontrol dengan menerapkan model pembelajaran konvensional

Instrumen yang digunakan dalam penelitian ini adalah tes objektif hasil belajar dan lembar observasi kemampuan bertanya. Tes yang digunakan dalam bentuk tes objektif yang berbentuk pilihan berganda sebanyak 30 soal berdasarkan hasil validasi terhadap 50 soal yang diujikan terhadap 34 siswa, dengan 5 pilihan soal (a, b, c, d, e). Setiap satu jawaban yang benar diberi skor 1. Kisi-kisi tes dapat dilihat pada Tabel 2.

Tabel 2. Kisi-Kisi Soal Tes Objektif

\begin{tabular}{|c|c|c|c|c|c|c|c|c|}
\hline \multirow[t]{2}{*}{ No } & \multirow[t]{2}{*}{ Indikator } & \multicolumn{6}{|c|}{ Kategori/ No. Soal } & \multirow{2}{*}{$\begin{array}{c}\text { Jumlah } \\
\text { soal }\end{array}$} \\
\hline & & C1 & C2 & C3 & C4 & C5 & C6 & \\
\hline 1 & $\begin{array}{l}\text { Struktur dan fungsi organ pernapasan } \\
\text { pada manusia }\end{array}$ & $2,3,25,30$ & $\begin{array}{l}6,11 \\
26,29\end{array}$ & $\begin{array}{c}4,10 \\
19\end{array}$ & 12 & 1,9 & & 14 \\
\hline 2 & $\begin{array}{l}\text { Mekanisme pernapasan pada } \\
\text { manusia }\end{array}$ & 22 & 20,28 & 5,18 & & & & 5 \\
\hline 3 & $\begin{array}{l}\text { Volume dan kapasitas paru-paru serta } \\
\text { frekuensi pernapasan manusia }\end{array}$ & $\begin{array}{c}8,13 \\
21,23,24,27\end{array}$ & & & & & 7 & 7 \\
\hline 4 & $\begin{array}{l}\text { Kelainan dan penyakit terkait sistem } \\
\text { pernapasan manusia }\end{array}$ & 14 & & 17 & 15,16 & & & 4 \\
\hline \multirow{2}{*}{\multicolumn{2}{|c|}{ Jumlah }} & 12 & 6 & 6 & 3 & 2 & 1 & 30 \\
\hline & & $40 \%$ & $20 \%$ & $20 \%$ & $10 \%$ & $5 \%$ & $\begin{array}{l}5 \\
\%\end{array}$ & $100 \%$ \\
\hline
\end{tabular}

\begin{abstract}
Observasi dilaksanakan untuk mengamati kemampuan bertanya siswa dalam kegiatan pembelajaran yang berlangsung dikelas dengan menggunakan lembar observasi. Observasi yang dilakukan dibantu oleh rekan peniliti. Dalam lembar observasi kemampuan bertanya siswa tersebut terdapat kriteria yang dinilai sesuai dengan tabel
\end{abstract}

dibawah ini. Sebelumnya instrumen soal digunakan terlebih dahulu diujicobakan untuk mengetahui validitas, reliabilitas, tingkat kesukaran, dan daya pembedanya. Arikunto (2011) menyatakan bahwa syarat-syarat tes layak digunakan atau tidak harus dilakukan uji validitas, reliabilitas, tingkat kesukaran soal dan daya pembeda. 
Tabel 3. Lembar Observasi Kemampuan Bertanya Siswa

\begin{tabular}{|c|c|c|c|c|c|}
\hline \multirow{2}{*}{ No } & \multirow{2}{*}{ ASPEK YANG DINILAI } & \multicolumn{4}{|c|}{ Tingkat capaian kerja } \\
\hline & & 1 & 2 & 3 & 4 \\
\hline 1 & Keberanian bertanya & & & & \\
\hline 2 & Ketepatan pertanyaan sesuai materi sistem pernapasan manusia & & & & \\
\hline 3 & Singkat dan kejelasan pertanyaan & & & & \\
\hline 4 & Kelogisan pertanyaan & & & & \\
\hline 5 & Tingkatan pertanyaan berdasarkan Taksonomi Bloom & & & & \\
\hline
\end{tabular}

$$
\text { Nilai }=\frac{\text { Shor yang didapat siswa }}{\text { Shor } \text { Total }} \times 100
$$

Kemampuan bertanya siswa di nilai secara keseluruhan dengan beberapa kriteria sebagai berikut.

$$
\begin{array}{ll}
81-100 & =\text { sangat baik } \\
60-80 & =\text { baik } \\
41-60 & =\text { cukup baik } \\
21-40 & =\text { kurang baik } \\
0-20 & =\text { kurang baik sekali (Mafika, 2015) } .
\end{array}
$$

\section{HASIL PENELITIAN}

Data hasil penelitian meliputi nilai pretes, postest untuk kemudian di uji normalitas, homogenitas, dan hipotesis. Deskripsi data hasil belajar yang memaparkan rata-rata, median, modus, standar deviasi, varian, minimum, maksimum dan rentangan. Skor rata-rata nilai pretes untuk kelas kontrol adalah 41,575 dengan nilai tertinggi 66 dan nilai terendah adalah 16 serta standar deviasinya adalah 15,83.
Sedangkan untuk nilai postest diperoleh nilai rata-rata nilai yaitu sebesar 79,25 dengan skor tertinggi adalah 90 dan nilai terendah yaitu 66 serta standar deviasinya sebesar 5,86. Sementara nilai pretest untuk kelas eksperimen sebesar 42,1 dengan nilai tertinggi 66 dan nilai terendah adalah 20 dengan standar deviasinya yaitu 15,94 . Sedangkan untuk nilai postest diperoleh rata-rata sebesar 82,9 dengan nilai tertinggi 93 dan nilai terendah 66 serta standar deviasi sebesar 6,3.

Tabel 4. Rata-Rata Standar Deviasi Pada Kelas Kontrol Dan Kelas Eksperimen

\begin{tabular}{rrrrrrrr}
\hline \multicolumn{3}{c}{ Kelas Kontrol } & \multicolumn{5}{c}{ Kelas Eksperimen } \\
\hline \multicolumn{2}{c}{ Pretest } & \multicolumn{2}{c}{ Postest } & & \multicolumn{2}{c}{ Pretest } & Postest \\
& & & & & & \\
\hline $\bar{X}$ & SD & & SD & $\bar{X}$ & SD & $\bar{X}$ & SD \\
41,575 & 15,83 & 79,25 & 5,86 & 42,1 & 15,94 & 82,9 & 6,3 \\
\hline
\end{tabular}

\section{Uji Normalitas}

Salah satu persyaratan analisis yang harus dipenuhi agar dapat menggunakan statistik parametrik adalah sebaran data setiap penelitian berdistribusi normal. Pengujian normal tidaknya data dilakukan dengan menggunakan rumus Liliefors (L). Syarat normal dipenuhi apabila $L_{\text {hitung }}<L_{\text {tabel }}$ pada taraf $\alpha=5 \%$. Hasil uji pretest diperoleh bahwa soal berdistribusi normal. 


\section{Uji Homogenitas}

Ringkasan uji homogenitas dari kedua sampel dapat dilihat pada Tabel 5 berikut.

Tabel 5. Ringkasan Uji Homogenitas

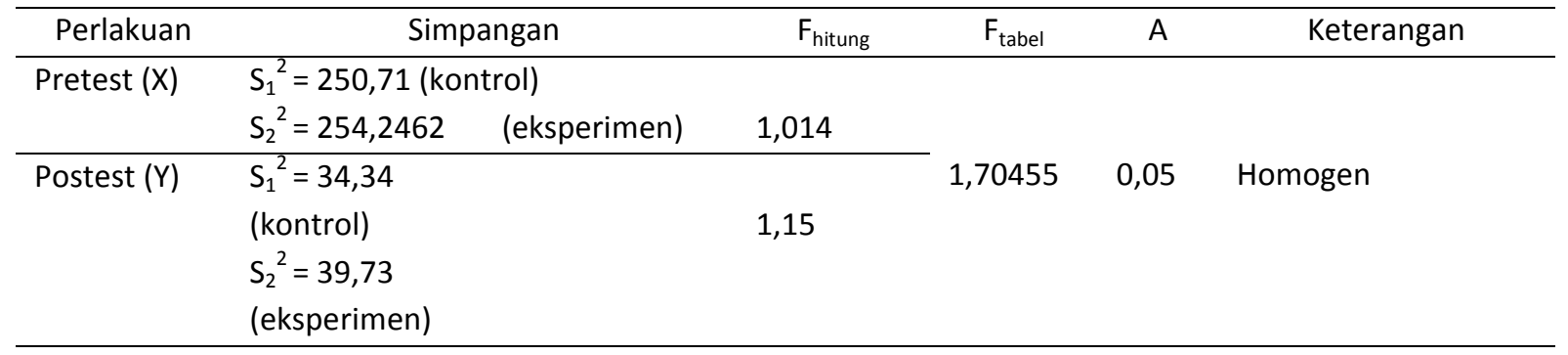

\section{Uji Hipotesis}

Pengujian hipotesis dilakukan menggunakan uji t. Hasil perhitungan pretest kedua kelas dengan uji $\mathrm{t}$ diperoleh $t_{\text {hitung }}=0,59$ dan $t_{\text {tabel }}=2,001$ karena $t_{\text {hitung }}<$ $t_{\text {tabel }}$ yaitu 0,59<2,001, maka $\mathrm{H}_{\mathrm{a}}$ diterima dan $\mathrm{H}_{0}$ ditolak. Jadi dapat disimpulkan bahwa tidaka da pengaruh yang signifikan nilai pretest antara kedua kelas sebelum diberikan kedua perlakuan. Hasil perhitungan postest kelas eksperimen diperoleh bahwa $t_{\text {hitung }}=16,3$ dan $t_{\text {tabel }}=2,001$. Dengan demikian $t_{\text {hitung }}>$ $t_{\text {tabel }}(6,66>2,001)$ hal ini berarti $H_{0}$ ditolak dan $H_{a}$ diterima (lampiran 26). Jadi dapat disimpulkan bahwa ada pengaruh yang signifikan menggunakan model pembelajaran kooperatif tipe Numbered Head Together terhadap hasil belajar siswa pada materi sistem pernapasan manusia di kelas XI IPA SMA N 1 Kutalimbaru T.P 2016/2017. Kemampuan bertanya siswa setelah diajarkan menggunakan model pembelajaran yang berbeda dapat dilihat pada Tabel 6 .

Tabel 6. Skor Penilaian Kemampuan Bertanya Siswa

\begin{tabular}{|c|c|c|c|c|c|c|}
\hline \multirow[t]{2}{*}{ Kelas } & \multicolumn{5}{|c|}{ Aspek yang dinilai } & \multirow{2}{*}{$\begin{array}{l}\text { Rata- } \\
\text { rata }\end{array}$} \\
\hline & Keberanian & Ketepatan & Singkat dan jelas & Kelogisan & Tingkatan & \\
\hline Eksperimen & $53,54 \%$ & $68,75 \%$ & $70 \%$ & $69,58 \%$ & $40,62 \%$ & 60,5 \\
\hline Kontrol & $38,12 \%$ & $35,62 \%$ & $36,04 \%$ & $36,45 \%$ & $16,25 \%$ & 32,5 \\
\hline
\end{tabular}

Rata-rata kemampuan bertanya siswa pada kelas eksperimen tergolong cukup baik dengan rata-rata 60,5\% sedangkan pada kelas kontrol tergolong kurang baik yaitu dengan rata-rata 32,5\%. Untuk lebih jelasnya, perbandingan skor kemampuan bertanya siswa pada kelas eksperimen dan kelas kontrol dapat dilihat pada grafik berikut.

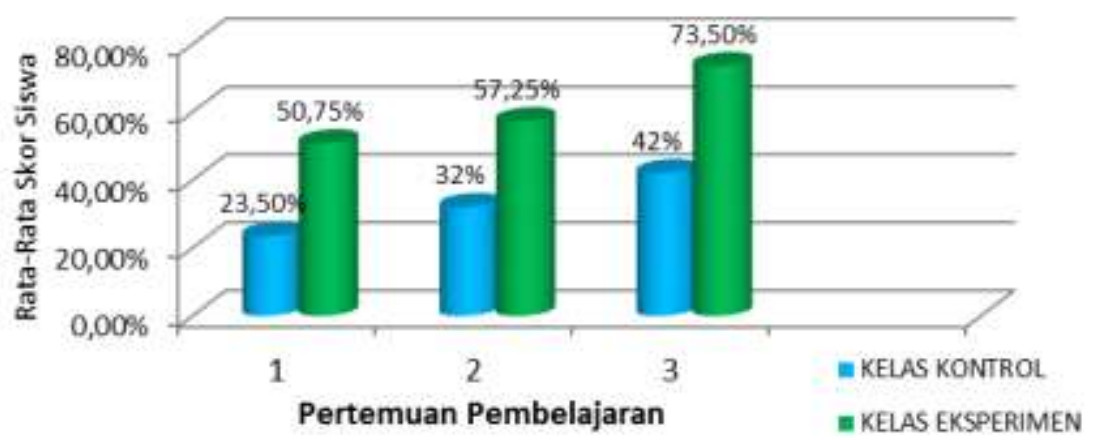




\section{Gambar 2. Kemampuan Bertanya Siswa Pada Setiap Pertemuan}

\section{PEMBAHASAN}

Berdasarkan hasil penelitian yang dilakukan setelah kedua kelas diajarkan menggunakan model pembelajaran kooperatif tipe NHT dan pembelajaran konvensional yaitu pada kelas eksperimen menggunakan model pembelajaran kooperatif tipe Numbered Head Together (NHT) dan kelas kontrol dengan menggunakan metode ceramah. Masing masing kelas diberikan postest untuk melihat adanya perbedaan hasil belajar pada kedua kelas yang diajarkan dengan perlakuan pembelajaran yang berbeda. Dari data postes kedua kelas diperoleh nilai rata-rata postes untuk kelas eksperimen sebesar 82,9 dan nilai rata-rata kelas kontrol 79,25. Hal ini menunjukkan bahwa penggunaan model NHT sangat membantu siswa kelas XI IPA di SMA N 1 Kutalimbaru dalam meningkatkan hasil belajar Biologi siswa. Hal tersebut sesuai dengan pendapat Trianto (2011) bahwa Numbered Head together (NHT) melibatkan banyak siswa dalam menelaah materi yang mencakup dalam suatu pelajaran dan mengecek pemahaman isi pelajaran.

Hasil uji normalitas dan uji homogenitas untuk kedua sampel diperoleh bahwa nilai pretest berdistribusi normal dan berasal dari populasi yang homogen. Hasil uji hipotesis untuk postest menggunakan uji $t$ diperoleh $t_{\text {hitung }}>t_{\text {tabel }}(6,66>2,001$ yang berarti terdapat pengaruh yang signifikan dalam penerapan pembelajaran kooperatif tipe Numbered Head Together (NHT) terhadap hasil belajar siswa pada materi sistem pernapasan manusia di kelas XI IPA SMA N 1 Kutalimbaru T.P 2016/2017.

Peningkatan rata-rata hasil belajar siswa yang diterapkan dengan menggunakan model pembelajaran kooperatif tipe Numbered Head Together (NHT) pada penelitian ini juga didukung oleh penelitian terdahulu yaitu Wahyuningsih dan Murwani (2015) di SMA N 2 yogyakarta pada materi Jarinagn hewan diperoleh ratarata hasil belajar pretes yaitu 64,23 dan postest sebesar 78,06 . Artinya ada pengaruh signifikann ketika siswa diajarkan dengan menggunakan model pembelajaran kooperatif tipe Numbered Head Together (NHT).
Keadaan diatas sejalan dengan beberapa penelitian yang menggunakan model kooperatif tipe NHT, diantaranya Febriana (2012) di SMA N 4 Siak pada pelajaran matematika diperoleh nilai rata-rata pretest pada kelas eksperimen 52,44 dan nilai postest 84,7 . Pada kelas kontrol diperoleh nilai rata-rata pretest siswa sebesar 50,71 dan postest sebesar 74 .

Keberhasilan pembelajaran yang telah dicapai dalam penelitian ini dapat terjadi karena kelebihan dari model pembelajaran kooperatif tipe Numbered Head Together (NHT) yang memotivasi siswa untuk lebih giat belajar, dimana kegiatan diskusi dalam model ini membuat variasi suasana pola diskusi kelas yang dapat memberikan siswa lebih banyak waktu berpikir untuk merespon dan saling bekerjasama antara siswa yang satu dengan siswa yang lainnya yang berbeda tingkat intelektual dan jenis kelaminnya dalam suatu kelompok, dengan kata lain bersifat heterogen. Adanya perbedaan kemampuan intelektual dalam satu kelompok dianggap mampu untuk meningkatkan hasil belajar siswa, karena siswa yang pintar dapat memberikan informasi kepada siswa yang kurang mampu dan sebaliknya sehingga dapat saling bekerjasama (Ibrahim, 2000).

Dalam Model NHT ini juga tidak mengharuskan siswa terus menghafal tetapi sebuah model yang memberikan kebebasan kepada siswa untuk mengeksplorasi pengetahuannya sendiri. Dalam model pembelajaran kooperatif tipe NHT, siswa dilibatkan secara aktif dalam proses pembelajaran dan berdiskusi dengan teman kelompoknya dalam mencari jawaban atas permasalahan yang diajukan. Hal ini juga didukung oleh Mahardiyanti (2014) bahwa model NHT dapat meningkatkan prestasi belajar siswa karena memiliki kelebihan yaitu: 1) setiap siswa siap untuk ditunjuk mengerjakan tugas yang diberikan oleh guru; 2) Siswa dapat berdiskusi secara sungguh-sungguh; dan 3) siswa yang memiliki kemampuan akademik lebih tinggi dapat mengajari temannya yang berkemampuan akademik rendah. Melalui kerjasama kelompok yang sungguhsungguh tentunya dapat meningkatkan pemahaman siswa terhadap suatu materi yang berdampak pada prestasi belajar siswa. 
JURNAL PELITA PENDIDIKAN VOL. 5 NO. 4

Sihotang, N., Djulia, E., Gurusinga, S.

Halaman : $389-397$

Dalam penelitian setelah kegiatan presentasi atau pemaparan jawaban, selalu ada sesi tanya jawab dan pemberian tanggapan. Pada aspek kemampuan bertanya atau menanggapi pertanyaan siswa sudah mulai aktif, terlihat dari beberapa siswa yang sudah berani mengajukan pertanyaan. Pada penelitian diperoleh kemampuan bertanya siswa di kelas eksperimen sebesar 60,5\% yatu termasuk kategori cukup baik dimana pertanyaan yang disampaikan tepat,logis, dan sesuai topik pembicaraan sedangkan dikelas kontrol sebesar 32,5 \% yaitu kategori kurang baik. Pada kelas eksperimen diperoleh rata-ratanya lebih tinggi dibandingkan kelas kontrol. Hal ini menunjukkan bahwa model NHT berpengaruh terhadap aspek kemampuan bertanya siswa. Dengan model pembelajaran NHT, seluruh siswa diberikan kesempatan yang sama untuk berbicara, baik bertanya ataupun menanggapi pertanyaan. Sejalan dengan itu, Lie dalam Yunansyah (2008) mengemukakan bahwa teknik Numbered Heads Together memberikan kesempatan kepada siswa untuk saling membagikan ide-ide dan juga mempertimbangkan jawaban yang paling tepat dari permasalahan yang diajukan oleh peneliti. Pada pelaksanaannya, siswa saling berdiskusi untuk menemukan jawaban yang paling tepat. Tutor sebaya pun terlihat saat proses pembelajaran dimana siswa yang telah mengerti akan jawaban dari tiap soal yang diajukan oleh peneliti bisa membagikan idenya atau pemahamannya kepada siswa yang belum mengerti sehingga adanya pemahaman yang baik mengenai materi yang dibelajarkan. Model pembelajaran Numbered Head Together (NHT) lebih mengedepankan kepada aktivitas siswa dalam mencari, mengolah dan melaporkan informasi dari berbagai sumber yang akhirnya dipresentasikan didepan kelas sehingga mendorong siswa untuk aktif (Komalasari, 2013).

Dari hasil dan pembahasan diatas, dapat disimpulkan bahwa pembelajaran Biologi dengan menggunakan model pembelajaran kooperatif tipe Numbered Head Together (NHT) pada materi sistem pernapasan manusia dapat meningkatkan hasil belajar dan kemampuan bertanya siswa. Maka pembelajaran biologi dengan menggunakan model pembelajaran kooperatif tipe Numbered Head Together (NHT)
pISSN : 2338 - 3003

elSSN : $2502-3217$

terhada[p hasil belajar dan kemampuan bertanya siswa pada materi sistem pernapasan manusia di kelas XI IPA SMA N 1 Kutalimbaru dinyatakan berpengaruh.

\section{KESIMPULAN}

Berdasarkan hasil dan pembahasan tersebut di atas, maka dapat disimpulkan sebagai berikut bahwa hasil belajar siswa pada materi sistem pernapasan manusia dengan menggunakan model pembelajaran kooperatif tipe Numbered Head Together di kelas XI IPA SMA N 1 Kutalimbaru sebesar 82,9. Kemampuan bertanya siswa pada materi sistem pernapasan manusia dengan menggunakan model pembelajaran kooperatif tipe Numbered Head Together di kelas XI IPA SMA N 1 Kutalimbaru sebesar 60,5\% yaitu kategori cukup baik.Ada pengaruh yang signifikan model pembelajaran kooperatif tipe Numbered Head Together terhadap hasil belajar dan kemampuan bertanya siswa pada materi sistem pernapasan manusia di kelas XI IPA SMA N 1 Kutalimbaru T.P 2016/2017.

\section{UCAPAN TERIMA KASIH}

Terima kasih terkhusus Bapak Drs. Adi Rustanto, M.Si. selaku Kepala Sekolah SMA N 1 Kutalimbaru, dan siswa-siswi kelas XI IPA SMA N 1 Kutalimbaru yang telah banyak membantu selama penelitian berlangsung.

\section{DAFTAR PUSTAKA}

Arikunto, S., (2013), Dasar-Dasar Evaluasi Pendidikan, Bumi Aksara, Jakarta.

Dewi, T, G., dan Yunansyah, (2013), Pengaruh Pembelajaran Kooperatif Tipe NHT Terhadap Hasil Belajar Siswa Pada Konsep Energi dan Perubahannya, Antologi, 1(2).

Komalasari, K., (2013), Pembelajaran Kontruktivisme, PT Bumi Aksara, Jakarta.

Mahardiyanti, T., (2014), Penerapan Metode Numbered Head Together (NHT) Untuk Meningkatkan Prestasi Belajar Matematika sSiswa Kelas V SD N 1 Mlilir Kecamatan Dalopo Kabupaten Madiun 2014/2015, Jurnal IImiah Pendidikan, 84-94. 
Halaman : $389-397$

Pakpahan, M, dan Riwayati., (2016), Perbedaan Hasil Belajar Menggunakan Model Pembelajaran Numbered Head Together (NHT) Dengan Think Pair Share (TPS) Pada Materi Ekosistem Dikelas VII, Jurnal Pelita Pendidikan, 4(2): 86-92.

Pujiati, L., (2008) Peningkatan Motivasi Dan Ketuntasan Belajar Matematika Melalui Pembelajaran Kooperatif Tipe STAD, Jurnal IImiah Pendidikan, 1(1): 1-20.

Sudjana, (2005), Metoda Statistika, Tarsito, Bandung.

Sudjana, N., (2009), Penilaian Hasil Proses Belajar Mengajar, PT Remaja Rosdakarya, Bandung.

Slavin, R., (2010), Cooperative Learning, Penerbit Nusa Media, Bandung.

Syah, M., (2010), Psikologi Pendidikan: Dengan Pendekatan Baru, Remaja Rosdakaya, Bandung.

Trianto, (2009), Mendesain Model-Model Pembelajaran Inovatif-Progresif, Kencana Prenada Media Group, Jakarta.

Wahyuningsih, D, dan Murwani, S., (2015), Peningkatan Aktivitas Dan Hasil Belajar Siswa Pada Pembelajaran Biologi Melalui Implementasi Model Numbered Head Together pada Siswa Kelas XI SMA Negeri 2 Yogyakarta, Jurnal Pendidikan Matematika Dan Sains, 3(1): 65-71.

Yuliana, L., (2010), Keterampilan Bertanya Guru Dalam Mengelola Proses Belajar, Fondasia, 2(10): 96105.

Zulfah, S., (2015), Penerapan Model NHT Pada Pembelajaran Sistem Pencernaan Makanan, Jurnal Penelitian Tindakan Kelas, 16(4): 24-28. 